\title{
Niezłomny w stanie wojennym
}

AdW. STANisŁaW KŁYS

Naczelna Rada Adwokacka

Księdza Życińskiego poznałem na samym początku stanu wojennego, w 1981 roku. Miałem wówczas kancelarię w robotniczej dzielnicy Krakowa - Nowej Hucie, w Zespole Adwokackim nr 12. Pewnego dnia zadzwonił telefon: „Pan mecenas Stanisław Kłys? Tu ksiądz Życiński. Czy mógłby pan podjąć się obrony studenta zatrzymanego przez Służbę Bezpieczeństwa za to, że przewoził zakazane pisma podziemne?”. Oczywiście natychmiast wyraziłem zgodę na obronę oskarżonego studenta.

Tak zaczęło się nasze porozumienie, dziś mogę powiedzieć - przyjaźń, wynikająca z łączącej nas wspólnej sprawy, pomocy potrzebującym w walce z przemocą. Ksiądz Józef Życiński zwracał się do mnie w rozmaitych sprawach związanych ze stanem wojennym, który był dla niego niezrozumiałą i niepojętą opresją, i nigdy nie mógł pojąć mentalności jego piewców. Na prośbę księdza Józefa Życińskiego, który angażował się w sprawy ludzi krzywdzonych, broniłem wielu: studentów, inteligentów, robotników, twórców 
i artystów Piwnicy pod Baranami, m.in. Piotra Skrzyneckiego, Zbigniewa Preisnera i Antoniego Krauzego. W obronach tych, zwłaszcza dotyczących „Piwniczan”, wraz ze mną występowała wielka znawczyni sztuki, bardzo ceniona przez Arcybiskupa, niezapomniana adwokat Janina Ruth Buczyńska, której imię nosi Klub Adwokatów w Krakowie. Arcybiskup Życiński przez cały okres stanu wojennego wspierał potrzebujących pomocy i był związany serdecznymi więzami z Adwokaturą Polską. Za tę niezłomną postawę $\mathrm{w}$ stanie wojennym, a także za starania o zachowanie systemu wartości istotnych dla nas, adwokatów, rozumienia godności człowieka, Arcybiskup Życiński otrzymał na Zamku Królewskim w Warszawie w 2008 roku odznakę „Adwokatura Zasłużonym”. Dziękując za to wyróżnienie, które otrzymał w czasie uroczystych obchodów 9o-lecia Adwokatury Polskiej, której zawołaniem jest „Polsce - wierność, praw i wolności - obrona, potrzebującym pomoc", powiedział, że adwokaci dali w stanie wojennym konsekwentne świadectwo wrażliwości i troski o godność człowieka. Adwokatura w państwie prawa jest i musi być jego niezbywalnym i koniecznym ogniwem, bez którego państwo nie może normalnie funkcjonować. Być może wyrok skazujący Jezusa był tak przerażająco niesprawiedliwy, gdyż Temidę reprezentował wtedy jedynie prokurator Piłat i środowisko manipulujące tłumem. Nie było natomiast adwokatów. Na czarnych kartach polskich dziejów pokazujących instytucjonalne łamanie prawa znajdujemy optymistyczne znaki odwagi i nonkonformizmu 
okazywane przez środowisko adwokatów. Można bowiem obalić komunizm, a potem zginąć wśród jego ruin. Arcybiskup dziękował adwokatom za świadectwo wrażliwych sumień, które pozwalają zachować niezależność od sytuacyjnych absurdów. Życzył, by świadectwo humanizmu pomogło łączyć wrażliwość dramatów człowieka z Wielkim Niesprawiedliwie Skazanym, nadając pracy adwokata ponadczasowy sens. Adwokatura Polska pamięta o swoim Arcybiskupie. Naczelna Rada Adwokacka w 2014 roku wydała sześciopłytowy album zatytułowany Ego Sum Ioseph Frater Vester: Józef Życiński in memoriam z nagraniami CD zawierającymi Jego homilie i wykłady oraz tak lubianą przez Niego muzykę organową, w wykonaniu wybitnego organisty prof. Andrzeja Białki, nagraną na organach w farze kościoła w Kazimierzu Dolnym nad Wisłą, w kościele pw. Nawrócenia św. Pawła w Lublinie i w Filharmonii Krakowskiej. W dołączonym do tego nagrania booklecie wspominają go m.in. Władysław Bartoszewski, ksiądz Michał Heller, biskup Grzegorz Ryś, poetka Ewa Lipska, prof. Jerzy Pomianowski.

Od przedwczesnej śmierci Arcybiskupa Józefa Życińskiego upłynęło pięć lat, a puste miejsce, jakie po sobie zostawil, pozostaje w dzisiejszym jakże trudnym czasie dla Polski i Kościoła pustym coraz bardziej.

Media - Kultura - Dialog. W piąta rocznicę śmierci arcybiskupa Józefa Życińskiego, red. ks. R. Nęcek, ks. W. Misztal, Kraków 2017, s. 229-231.

DOI: http://dx.doi.org/10.15633/9788374385848.18 